\title{
20 Years of Medicinal Chemistry - Always Look at the Bright Side (of Life)
}

\author{
Christoph Boss*
}

SCS Industrial Science Award 2019

\begin{abstract}
This paper summarizes a personal perspective on key learnings from projects the author was involved in over the last 20 years. For example, the discovery of macitentan, the most successful molecule to date from this personal collection, marketed by J\&J for the treatment of pulmonary arterial hypertension (PAH). ${ }^{[1]}$ Then the discovery of ACT-462206, a dual orexin receptor antagonist for the treatment of insomnia disorder with a serendipitously short story from the screening hit to the drug ${ }^{[2]}$ followed by the identification of daridorexant, another dual orexin receptor antagonist. Daridorexant successfully passed first pivotal phase 3 clinical trial in April 2020 for the treatment of insomnia disorder ${ }^{[3]}$ ("Good things come to those who wait"). Finally, ACT-451840, an antimalarial drug with a novel mechanism of action, identified in the perfect collaboration between academia and industry. The compound is in phase 2 clinical development. ${ }^{[4]}$ In addition, the importance of the screening compound collection is briefly discussed, as a key asset for drug discovery. The measures Idorsia implemented to obtain valuable hits from high-throughput screening (HTS) campaigns are elaborated. ${ }^{[5]}$ Drug discovery is a multi-disciplinary business with unlimited exciting challenges asking for excessive optimism when tackling them in a playful manner.
\end{abstract}

Keywords: Endothelin receptor antagonist · G-protein-coupled receptor (GPCR) - Insomnia disorder · Malaria • Medicinal chemistry $\cdot$ Orexin receptor antagonist $\cdot$ Screening compound collection

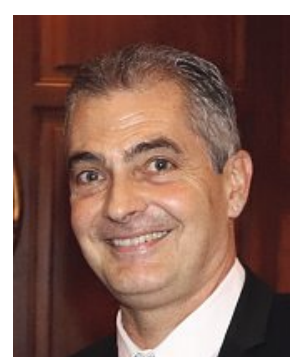

Christoph Boss studied chemistry at the University of Bern and received his $\mathrm{PhD}$ on 'Synthesis, Structure and Reactivity of Cycloalkadiynes' (Prof. Dr. Reinhard Keese) in 1996. After post-doctoral studies at the Scripps Research Institute in the group of Prof. Dr. Julius Rebek, Jr., he joined the process development group of Säurefabrik in Schweizerhall for one year. He then moved to Actelion Pharmaceuticals Ltd at the beginning of 1999, where he first worked as laboratory head and project leader, then as group leader in medicinal chemistry, later on as group leader in chemistry technologies. Upon the acquisition of Actelion by Janssen Pharmaceutical, a company of Johnson\&Johnson, Dr. Boss joined the newly established company Idorsia Pharmaceuticals Ltd as group leader oncology chemistry in 2017. In July 2019 Dr. Boss was promoted to department head of drug discovery chemistry and became a member of the Idorsia leadership team. During his now 21 years with Actelion and Idorsia, he was a member of the team who discovered macitentan and aprocitentan. He contributed to the discovery of several renin inhibitors going into clinical trials, to the antimalarial ACT-451840 which is in Phase II clinical development and to the CRTH2 antagonist ACT-774312 also in Phase II clinical development. His team focused on the discovery of orexin receptor antagonists from 2006 onward and identified three clinical candidates, ACT-462206, a DORA, ACT-539313, a SO1RA, and ACT-541468, another DORA which became daridorexant and successfully finished pivotal Phase 3 clinical trials for the treat- ment of insomnia disorder in April 2020. Dr. Boss is co-author or co-inventor on approximately 220 scientific papers or published patent applications.

\section{The Early Days: Identifying the 'Best' Endothelin Receptor Antagonists}

In December 1997, Actelion Pharmaceuticals was founded by Martine and Jean-Paul Clozel, Walter Fischli and Thomas Widmann, four key players in the field of endothelin (ET) research, who discovered several novel endothelin receptor antagonists inhibiting the signaling of the endothelin A (ETA) and the endothelin B (ETB) receptor. Their early work, performed at Hoffmann-LaRoche, described the ET system in physiology as well as in pathology in detail and pointed out the positive potential of inhibiting the signaling of the ET-receptors in a diverse set of cardiovascular disorders. ${ }^{[6-10]}$ Medicinal chemistry research at Roche resulted in the identification of orally active small molecule endothelin receptor antagonists, one of which was bosentan (1). ${ }^{[11,12]}$ After Roche decided to stop further clinical development of bosentan (1) in congestive heart failure after Phase II, Actelion obtained a license from Roche to continue bosentan's clinical development beyond congestive heart failure. In parallel, the founders of Actelion wanted to establish a sustainable research organization to ensure continuity of new molecules for clinical development. That was when I got a job offer from Actelion which I happily accepted. I joined a very young company and after having set-up the labs and the offices the team of young researchers I was part of, received as a first task, to identify a novel, dual endothelin receptor antagonist (ERA) with improved properties compared 
to bosentan (1). The detailed story was recently described by my colleague Martin H. Bolli in this journal.[13] Therefore, I will only briefly summarize our quest for the best ERA.

\section{The Endothelin System}

The endothelium is an organ consisting of a single layer of cells that separate the blood vessel wall from the blood stream. It is of key importance for the maintenance of blood vessel tone and therefore, for blood pressure regulation. It also provides a non-adhesive surface to prevent blood clot formation. Endothelial cells produce for example endothelin, nitric oxide or prostacyclin. While endothelin has pronounced vasoconstrictive properties and promotes cell proliferation, prostacyclin and nitric oxide result in vasodilation, prevent platelet adhesion and inhibit vascular smooth muscle cell proliferation. In healthy situations the actions of endothelin, prostacyclin and nitric oxide are in balance. In pathological situations an overproduction of endothelin combined with low levels of nitric oxide and prostacyclin result in vasoconstriction, the promotion of fibrotic processes and vascular and cardiac remodeling. The endothelin system consists of three structurally related peptides, endothelin-1 (ET-1), endothelin-2 (ET-2) and endothelin-3 (ET-3) and two G-protein-coupled receptors (GPCR's), the ETA and ETB receptors, which are activated by the three peptides. ${ }^{[14,15]}$ The ETA-receptor is most strongly activated by ET-1, a 21-amino acid peptide. The ETB receptor is activated with high affinity by all three ET-peptide homologs. ${ }^{[16]}$ Historically, ETA-selective antagonists and dual ETA/ETB antagonists were considered as treatment options for a broad variety of cardiovascular diseases such as congestive heart failure, chronic heart failure, acute heart failure, myocardial infarction, cerebral vasospasm, subarachnoid hemorrhage, renal failure, hypertension, pulmonary hypertension and prostate cancer. This huge therapeutic potential resulted in significant activities in the pharmaceutical industry to obtain small molecule ERAs with diverse selectivity profiles. ${ }^{[17]}$ Our analysis of the situation led to the decision to target dual ETA/ETB receptor antagonists, as these showed higher efficacy and better safety in animal models. ${ }^{[18,19]}$ We had then to decide in which chemical space we wanted to start working. We selected multiple starting points, from which we prepared and tested thousands of ERAs. The scope of this program reflects the countless dead-ends and detours we encountered as we balanced our multifactorial approach, in which potency, a balanced selectivity profile, and safety were program goals. One of our starting points was bosentan (1), a pyrimidine-based molecule. ${ }^{[20]}$ In Fig. 1 our medicinal chemistry program from the starting point bosentan (1) to the discovery of macitentan $(\mathbf{1 0})$ is summarized. ${ }^{[1,17,21]}$

Over the course of our medicinal chemistry program, we modified structure $\mathbf{1}$, including by adding specifically designed new structural features. We worked on the sulfonamide moiety, increasing the distance between the phenyl ring and the sulfur by putting a double bond in between. We also removed the t-butylsubstituent on the phenyl ring. This resulted in phenylethane sulfonamide 2 with activity on both endothelin receptors comparable to our starting point $\mathbf{1}$. Reducing the double bond to a single bond gave 3, exhibiting similar ETA antagonistic activity but reduced potency on the ETB receptor. We also attached a pyrimidine ring to the ethylene glycol moiety and obtained 4 . This resulted in a $\sim 3$-fold potency gain on both receptors. Switching from an unsubstituted pyrimidine unit to, for example a 5-bromo-pyrimidine moiety (5) delivered highly potent ERAs. These molecules were large and rather lipophilic, increasing the probability of poor DMPK and safety behavior, based on low aqueous solubility, low microsomal metabolic stability or cytochrome inhibition. ${ }^{[22-24]}$ We removed the phenyl ring from the sulfonamide part resulting in, for example, an almost equipotent butane sulfonamide $\mathbf{6}$. The key step towards the discovery of $\mathbf{1 0}$ (macitentan) was the replacement of the sulfonamide moiety by the sulfamide moiety, to this date unknown in the field of ERAs. Even though 7 had similar molecular weight when compared to $\mathbf{5}$, the introduction of the sulfamide functionality introduced surprising and interesting features, such as increased potency on both endothelin receptors, in particular the ETB receptor. We removed the pyrimidine ring attached to the 2-position of the core pyrimidine, which reduced molecular weight and resulted in an only minor loss of potency, as can be seen with $\mathbf{8}$. Replacing the 2-methoxyphenoxy unit attached to the 5 position of the core pyrimidine ring, by a directly linked phenyl-ring yielded a relative potency gain (e.g. 9). Further in detail SAR investigations of the sulfamide functionality and further investigation into the the peripheral aromatic systems finally culminated in $\mathbf{1 0}$ (macitentan). During our quest for the 'best' ERA, we regularly profiled our compounds for ex vivo activity on rat aortic rings (ETA antagonistic potency) and rat tra-
Fig.1. Our medicinal chemistry program from starting point bosentan (1) to the discovery of macitentan (10). Below the molecular structure the antagonistic potency towards both the ETA and the ETB-receptor, measured in a radioligand binding assay, are depicted.
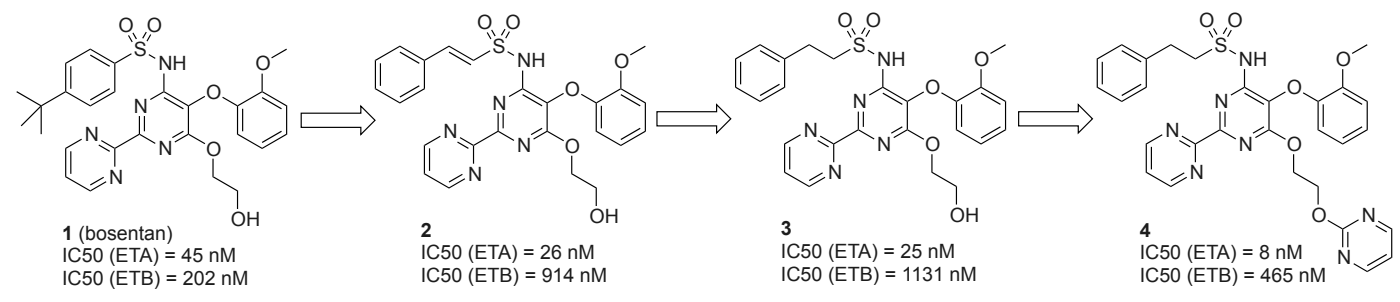
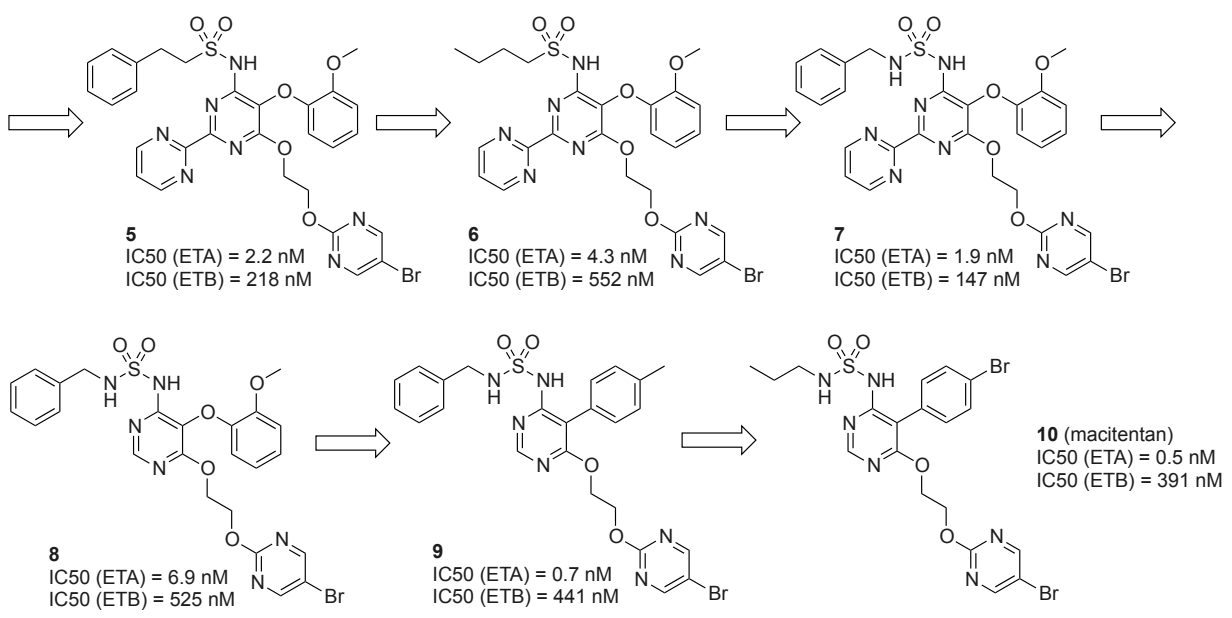
chea rings (ETB antagonistic potency) and in in vivo experiments in telemetered Dahl-salt sensitive hypertensive rats. Promising compounds were also characterized in in vitro DMPK and safety assays as well as for their physicochemical properties.

The in vivo efficacy data of our starting point 1 (bosentan) and the 'best' endothelin receptor antagonist 10 (macitentan) in male Dahl-salt sensitive hypertensive rats is depicted in Fig. 2.

Bosentan (1)

A)

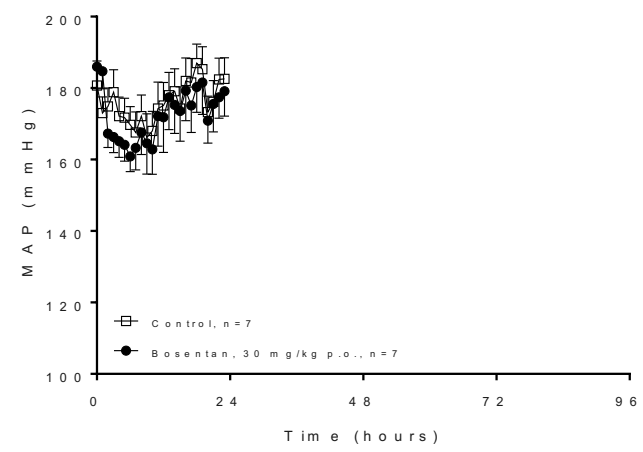

EXP: $1938+1960$

Max effect: $-8 \pm 3 \mathrm{mmHg}$ (6 hour mean)

ABC: $-44 \pm 27 \mathrm{mmHg}^{*} \mathrm{~h}(12 \mathrm{~h})$

B)

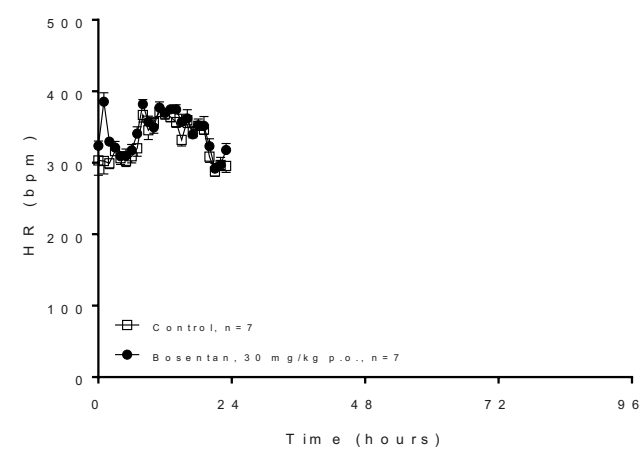

EXP: $1938+1960$ important to guarantee survival.[26] It is as well involved in the modulation of emotions related to stress and reward, among other functions. The orexins and their receptors are expressed in neurons and can also be found in non-neuronal cells and tissues. [27]

The orexin system consists of two orexin peptides, orexin $\mathrm{A}$ (OxA, 33 amino acids) and orexin $\mathrm{B}$ (OxB, 28 amino acids). They are generated by multiple enzymatic reactions from the common
Macitentan (10)

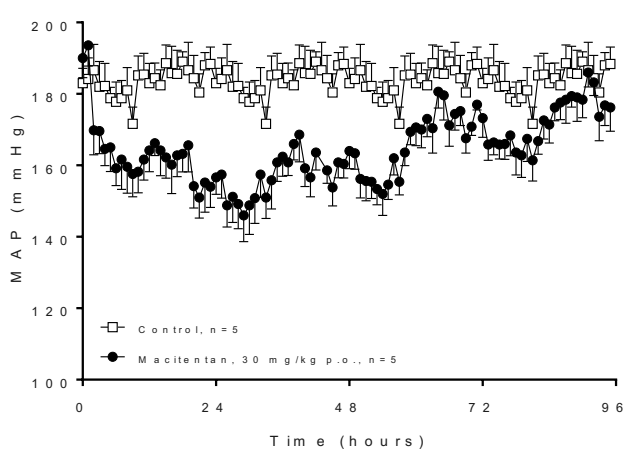

EXP: 1943

Max effect: $-32 \pm 4 \mathrm{mmHg}$ (6 hour mean) ABC: $-1780 \pm 43 \mathrm{mmHg}^{*} \mathrm{~h}$ (96h)

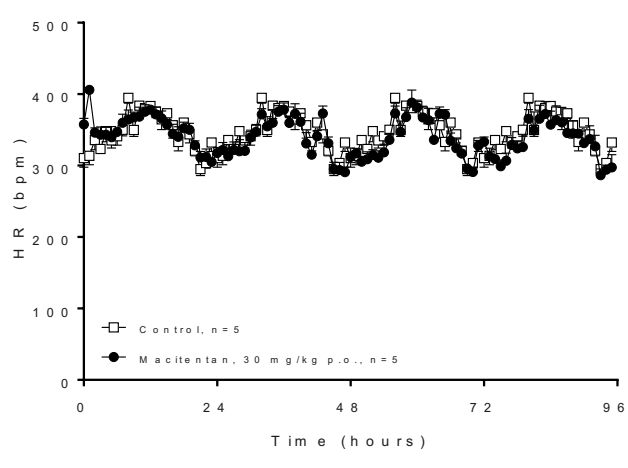

EXP: 1943

Fig. 2. A) Effects of Bosentan (1) and Macitentan (10) on MAP in conscious male Dahl salt sensitive rats; B) Effects of Bosentan (1) and Macitentan (10) on HR in conscious male Dahl salt sensitive rats

Fig. 2 impressively shows the progress made from the first endothelin antagonist marketed for the treatment of pulmonary hypertension (bosentan (1)) to the 'best' endothelin antagonist marketed for pulmonary hypertension (macitentan (10)) which successfully finished clinical development and was approved by the health authorities in 2013 and is marketed as Opsumit ${ }^{\circledR}$ by Johnson\&Johnson. In this experiment bosentan (1) at a dose of $30 \mathrm{mg} / \mathrm{kg}$ shows a blood pressure lowering effect over 12 hours, whereas macitentan (10) at the same dose shows an effect over 96 hours with a much stronger amplitude than bosentan (1). Both compounds, importantly, have no effect on heart rate.

A detailed summary of the complete preclinical characterization of macitentan (1) can be found in ref. [12].

\section{The Big Challenge: The Urgent Need for a 'Perfect' Dual Orexin Receptor Antagonist}

\section{The Orexin System}

The orexin system (also called hypocretin system) was independently discovered in 1998 by the research teams of de Lecea and Yanagisawa. ${ }^{[25]}$ It is a neuropeptide-G-protein-coupled receptor (GPCR) system which has a key role in the regulation of vigilance as an adaptive behavior to various physiological processes, precursor prepro-orexin. The orexin system is highly conserved across different mammalian species. Orexin-producing neurons are localized in the perifornical area, the lateral hypothalamus and the dorsomedial hypothalamic nucleus. The orexin peptides are released from the neurons in a $\mathrm{Ca}^{2+}$ sensitive manner and can then bind to the two related GPCRs, the orexin-1 (Ox1) receptor (425 amino acids) and the orexin-2 (Ox2) receptor (444 amino acids), which show an amino acid homology of 64\%. ${ }^{[28]}$ The OxA peptide, containing two disulfide bridges, binds with similar affinity to both orexin receptors. The $\mathrm{OxB}$ peptide shows significantly higher affinity for the Ox 2 receptor. Their signaling biology is rather diverse. Orexin producing neurons project widely to brain areas expressing differently one and/or both orexin receptors (Fig. $3) .{ }^{29]}$ Specifically looking at areas involved in the regulation of wakefulness, orexin neurons project to histaminergic neurons of the tuberomammillary nucleus (expressing mainly the Ox 2 receptors), noradrenergic neurons of the locus coeruleus (expressing mainly the Ox1 receptors), serotoninergic neurons of the dorsal raphe, dopaminergic neurons in the ventral tegmental area and cholinergic neurons in the basal forebrain and the pedunculopontine and lateral dorsotegmental nuclei (expressing both). ${ }^{[30]}$ Such differences in expression patterns suggest different physiological roles for the different receptors. ${ }^{[29,31]}$ 


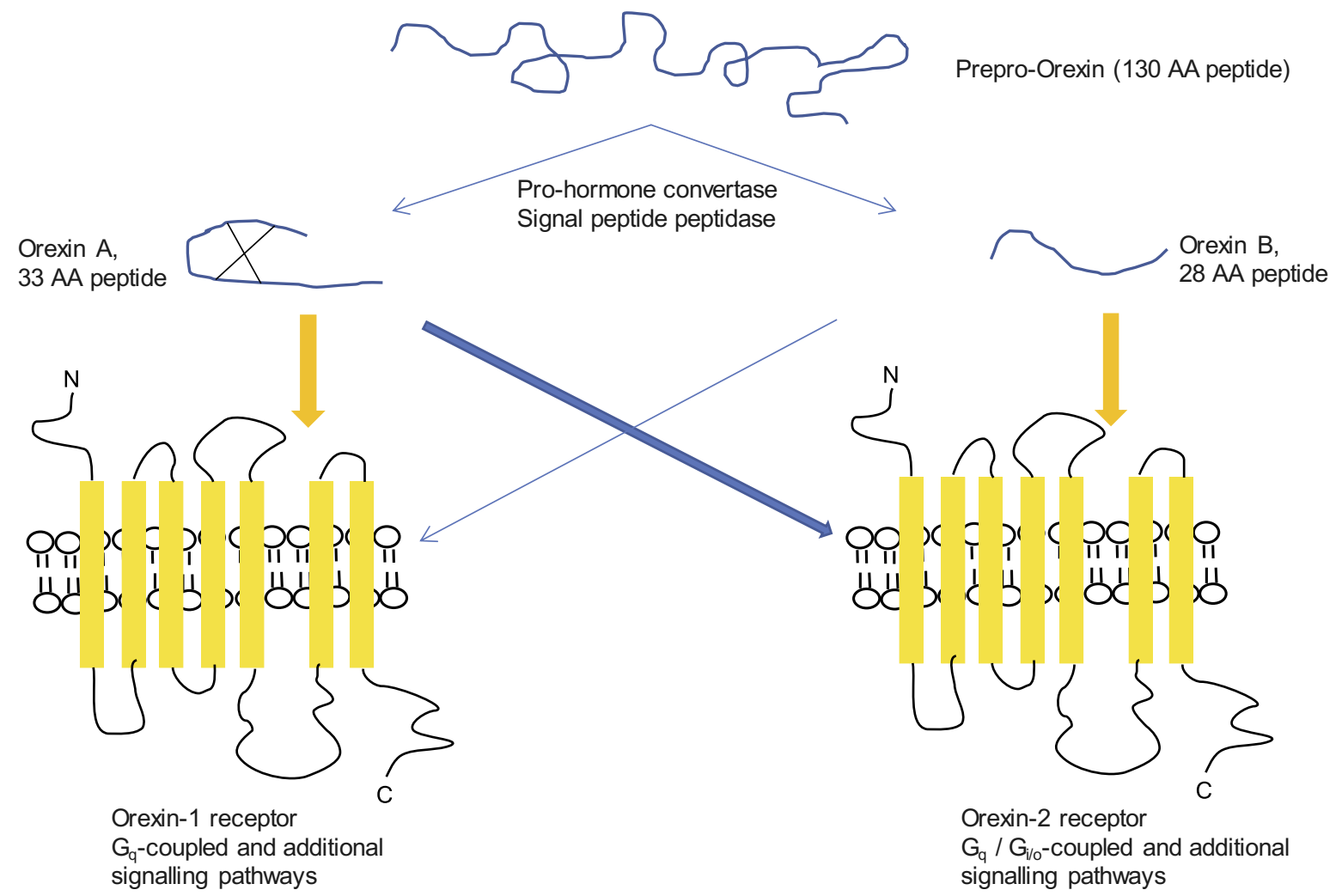

Fig. 3. The orexin system; Two receptors (orexin-1 receptor (Ox1); orexin-2 receptor (Ox2)) and two peptides (orexin A (OxA); orexin B (OxB))

Shortly after its discovery, evidence from human and animal studies established the link between dysfunction of the orexin system and the chronic sleep disorder narcolepsy type 1 (with cataplexy, i.e. a sudden episode of muscle weakness triggered by emotions), emphasizing the important role of this system in the regulation of sleep and wakefulness. ${ }^{[32]}$

Studies with different brain penetrant small molecule orexin receptor antagonists with different selectivity profiles helped in understanding the different aspects of the orexin system. For example, administration of the dual orexin receptor antagonist (DORA) almorexant (11) to healthy rats, dogs and humans resulted in a transient and reversible blockade of both orexin receptors and promoted somnolence in a dose-dependent manner without causing cataplexy. ${ }^{[33]}$ In contrast to GABA-A receptor modulators, a key aspect of DORAs is the maintenance of physiological sleep architecture with an increase of the time spent in both non-REM and REM sleep. ${ }^{[33-35]}$ Proof-of-concept studies and clinical phase III studies with almorexant (11) showed improved sleep onset latency and sleep maintenance in patients suffering from insomnia disorder, indicating an important role of the orexin system in the hyperarousal state related to insomnia.[36] Almorexant (11) unfortunately had to be discontinued at Actelion and so far did not reach the insomnia patients in need of a safe drug. ${ }^{[37,38]}$ The goal of the project at the time I started to work on it, was to come up with a new DORA with an improved profile compared to almorexant (11). We started the project with a high throughput screening of our screening compound collection and identified compound $\mathbf{1 2}$, a proline sulfonamide, as one interesting starting point. The molecule had a low molecular weight and contained only two (hetero)aromatic ring systems resulting in a high ligand efficiency. Modification of both exit-vectors, the sulfonamide as well as the anilide resulted in the identification of 13 (ACT-462206) which was selected for preclinical and clinical development (Fig. 4). Serendipitously, we needed only about 250 molecules to get from screening hit $\mathbf{1 2}$ to $\mathbf{1 3}$, clearly by far the shortest path in the author's experience from screening hit to clinical candidate. ${ }^{[2]}$ After phase I studies, ${ }^{[39]}$ clinical development was stopped and compound $\mathbf{1 3}$ was repurposed for development in animal healthcare. It served us as the starting point for further modifications in our quest for the 'perfect' DORA.

Certain modifications investigated replacements of the anilide moiety, to avoid a potential genotoxicity flag in future derivatives. Compound 14 represents an example with a pyridyl replacement. In $\mathbf{1 5}$ the anilide was replaced by a cyclohexyl-amide unit and in 16 a quinuclidine moiety was introduced. Unfortunately, these attempts resulted in a loss of orexin antagonist activity. As a next option, the amide functionality was integrated in a bicyclic heteroaryl system. We chose the benzimidazole system. Compounds $\mathbf{1 7}$ and $\mathbf{1 8}$ indicate that this was tolerated and that the activity seemed to be dependent on the substitution pattern of the benzimidazole group. We also substituted the sulfonamide functionality by a carbamide unit as exemplified with 19. This change resulted in a surprisingly strong increase in orexin receptor antagonist potency, especially towards the Ox2 receptor when comparing 18 to 19.

Then, we performed core modifications summarized in Fig. 5. Replacing the pyrrolidine ring in $\mathbf{1 9}$ with a piperidine in $\mathbf{2 0}$ resulted in a loss of activity mainly on the orexin 2 receptor. The bridged ring system in $\mathbf{2 1}$ which is reminiscent not only of a piperidine but also of a pyrrolidine, resulted in a significant gain of orexin antagonist potency towards both receptors. Saturated heterocyclic cores such as thiomorpholine (22) or morpholine (23) resulted again in less active compounds. We focused further scaffold hopping efforts back to compounds based on a proline core. Compound $\mathbf{2 4}$ served as a reference, with no additional substituent attached to the pyrrolidine unit. Derivatives $\mathbf{2 5}$ to $\mathbf{2 9}$ exemplify diversely substituted pyrrolidine cores. To our surprise, additional substitution on the pyrrolidine core in this series did not have strong effects on orexin antagonist activity. For further work we decided to focus on compounds based on the 2-methyl substituted pyrrolidine core as exemplified in $\mathbf{2 8}$. The additional methyl group in position 2 of the pyrrolidine ring had several advantages, e.g. enhanced chemical and metabolic stability and full prevention of racemization of the chiral center. As previously seen, activity could be affected by substitution of the benzimidazole system. Before discussing this 
<smiles>CNC(=O)[C@H](c1ccccc1)N1CCc2cc(OC)c(OC)cc2[C@H]1CCc1ccc(C(F)(F)F)cc1</smiles><smiles>O=C(Nc1cccc(S)c1)C1CCCN1S(=O)(=O)c1ccc(Br)s1</smiles>

Fig. 4. Almorexant (11), the first DORA in human clinical development; The proline-sulfonamide program from 12 to 13; First steps towards daridorexant (37), by modulating the anilide part of $\mathbf{1 2}$.

11 (almorexant)<smiles>COc1ccc(S(=O)(=O)N2CCCC2C(=O)Nc2cc(C)cc(C)n2)cc1</smiles><smiles>COc1ccc(S(=O)(=O)N2CCCC2c2nc3cccc(C)c3[nH]2)cc1</smiles><smiles>COc1cccc2nc(C3CCCN3S(=O)(=O)c3ccc(Cl)cc3)[nH]c12</smiles><smiles>COc1cccc2nc([C@@H]3CCCN3C(=O)c3cc(C)ccc3-n3nccn3)[nH]c12</smiles>

19

IC50 (Ox1) $=241 \mathrm{nM}$

IC50 $(\mathrm{Ox} 2)=30 \mathrm{nM}$<smiles>COc1cccc2nc(C3CCCCN3C(=O)c3cc(C)ccc3-n3nccn3)[nH]c12</smiles>

20

IC50 (Ox1) $=296 \mathrm{nM}$ IC50 $(\mathrm{O} \times 2)=369 \mathrm{nM}$

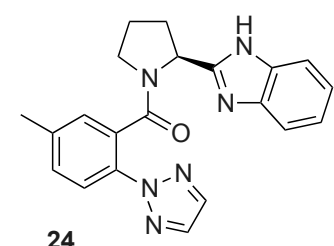

IC50 (Ox1) $=2020 \mathrm{nM}$ IC50 $(\mathrm{O} \times 2)=397 \mathrm{nM}$

$\mathrm{MeO}$

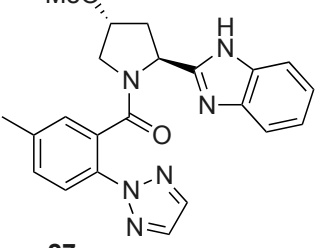

27

IC50 (Ox1) $=1610 \mathrm{nM}$ IC50 (Ox2) $=329 \mathrm{nM}$<smiles>COc1cccc2nc(C3C4CCC(C4)N3C(=O)c3cc(I)ccc3-n3nccn3)[nH]c12</smiles>

21

IC50 $(\mathrm{O} \times 1)=13 \mathrm{nM}$ IC50 $(\mathrm{Ox} 2)=12 \mathrm{nM}$<smiles>COc1cccc2nc(C3CSCCN3C(=O)c3cc(C)ccc3-n3nccn3)[nH]c12</smiles>

22

IC50 (Ox1) $=456 \mathrm{nM}$ IC50 $(\mathrm{O} \times 2)=2850 \mathrm{nM}$<smiles>COc1cccc2nc(C3COCCN3C(=O)c3cc(C)ccc3-n3nccn3)[nH]c12</smiles>

23

IC50 (Ox1) $=1440 \mathrm{nM}$ IC50 (Ox2) = $5650 \mathrm{nM}$

Fig. 5. Core modifications.

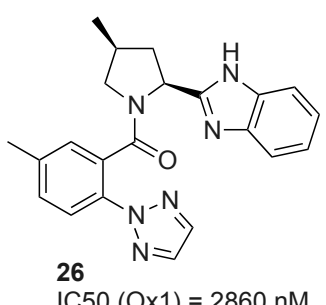

IC50 (Ox1) $=2860 \mathrm{nM}$

IC50 (Ox1) $=2740 \mathrm{nM}$ IC50 $(\mathrm{O} \times 2)=286 \mathrm{nM}$

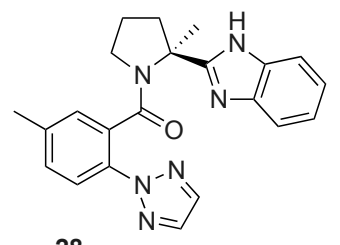

28

IC50 $(\mathrm{O} \times 1)=280 \mathrm{nM}$ IC50 (Ox2) $=1010 \mathrm{nM}$

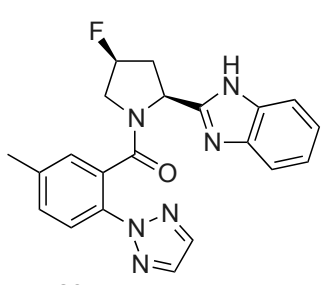

29

IC50 (Ox1) $=5430 \mathrm{nM}$ IC50 $(\mathrm{Ox} 2)=1840 \mathrm{nM}$ aspect, it is time to briefly explain how we assessed our orexin antagonist compounds for their pharmacological activity.

Orexin neurons are known to be active to maintain wakefulness and to be silent during sleep. ${ }^{[30 c]}$ Recording of orexin neurons in rats across the sleep-waking cycle show that they maximally discharge during active waking, when postural muscle tone is high in association with movement, decrease discharge during quiet waking and virtually cease firing during sleep... Sleep is divided into two states; non-rapid eye movement (NREM) and rapid eye movement (REM) sleep, NREM sleep representing approximately 
75 to $80 \%$ of the sleeping time in normal young adults. ${ }^{[40]}$ During REM sleep, the electroencephalogram (EEG) is desynchronized, muscles are atonic, and dreaming is typical. In contrast, NREM sleep includes a variably synchronous cortical EEG and is associated with low muscle tonus and minimal psychological activity. ${ }^{[40]}$ The typical pattern of sleep begins in NREM sleep and progresses through deeper NREM stages (stages N2 and N3 using the updated definitions) before the first episode of REM sleep which occurs approximately 80 to 100 minutes later. Thereafter, NREM sleep and REM sleep cycle with a period of approximately 90 minutes. NREM stages N3 concentrate in the early NREM cycles, and REM sleep episodes lengthen across the night. This shows that sleep is a very structured phenomenon. Whereas the exact function of sleep is still a matter of debate, it is key to maintain physical and mental health and it seems that each sleep stage has its role to play. ${ }^{[41]} \mathrm{An}$ average of eight hours of sleep per night is recommended for adults, meaning that humans spend one third of their lifetime sleeping.

Insomnia is a sleep disorder characterized by difficulty falling asleep (assessed by measuring the latency to persistent sleep), difficulty staying asleep (assessed by looking at the time someone stays awake after sleep onset) and daytime functioning impairment. It is described as a disorder of hyperarousal.[40,42] Whereas sleep and wakefulness are controlled by a complex system of interactions involving different neuronal populations in the brain, genetics and environmental factors, the orexin system is recognized as key for the stabilization of wakefulness. Preclinically, in conditions of sleep deprivation in rodents and monkeys, several studies led to the conclusion that sustained wakefulness was supported by the activation of the orexin system to compete with a homeostatic sleep pressure signal, with high orexin levels preventing sleep. ${ }^{[43]}$ Blocking the orexin receptors with a brain penetrant small molecule orexin receptor antagonist prevents the orexin peptides from keeping us awake and therefore allows us to sleep. Fig. 6A summarizes the experimental setting of how we assessed the efficacy of our orexin receptor antagonists during the drug discovery phase/preclinical research in a non-invasive animal model. Rats were implanted with telemetry transmitters. After recovery from surgery, the electromyogram (EMG for muscle activity) and the EEG (for brain activity) were continuously recorded in those telemetered rats freely moving in their home cages. The patterns of muscle- and brain activity together allowed the expert to de- duce in which of the four stages, active wake, quiet wake, NREM sleep or REM sleep a rat was. In addition, the system recorded home cage activity and body temperature. Fig. 6B explains the experiments we performed. Rats are more active during the night and sleep more during the day. This is visualized with the additional graph showing the $24 \mathrm{~h}$ circadian rhythm of the time spent sleeping per hour during one night (graph square) and one day. For each experiment, a $24 \mathrm{~h}$ period of baseline was recorded. The drug was then administered at the beginning of the night active phase and the effect of the drug was afterwards analyzed. By this schedule we artificially model insomnia (an (hyper)arousal state), even though rats were healthy. If the drug significantly increased the time spent asleep during the active phase it was assumed that the drug had sleep promoting effects in insomnia.

In Fig. 7A an example of the results of such an investigation is summarized. Compound 30, a potent DORA, which efficiently penetrated into the brain (data not shown here), was investigated at different orally administered doses of $3 \mathrm{mg} / \mathrm{kg}, 10 \mathrm{mg} / \mathrm{kg}$ and 30 $\mathrm{mg} / \mathrm{kg}$. The graph in Fig. 7A represents the time spent in the different sleep and wake stages as a percentage to the $6 \mathrm{~h}$ nighttime period following administration. The first row shows the normal sleep and wake pattern of the group of rats studied at night under vehicle treatment and is followed by the sleep and wake pattern following different doses of compound $\mathbf{3 0}$ and finally the sleep pattern of the rats during the resting phase (physiological day). The vehicle part of the graph in our setting represents the (hyper) arousal state as a model of insomnia and the physiological day graph represents normal sleep. Compound $\mathbf{3 0}$ dose-dependently increased both the time spent in non-REM and REM sleep without exceeding the amount or the proportion of sleep observed in a "physiological sleep" period. Compound $\mathbf{3 0}$ exhibited statistically significant effects at $30 \mathrm{mg} / \mathrm{kg}$. The compound, when broadly profiled, showed signs of phototoxicicity and was therefore not an ideal candidate for further development.

The phototoxicity was assigned to the dimethoxy substitution pattern of the benzimidazole moiety. We performed further variations of the substitution pattern at the benzimidazole and modified the triazolo-substituted benzoic acid part. This resulted in a series of highly potent DORAs as shown with $\mathbf{3 1}$ to $\mathbf{3 6}$. The 4-methyl5-chloro substitution pattern was identified as preferential for orexin receptor antagonist potency combined with metabolic

A)
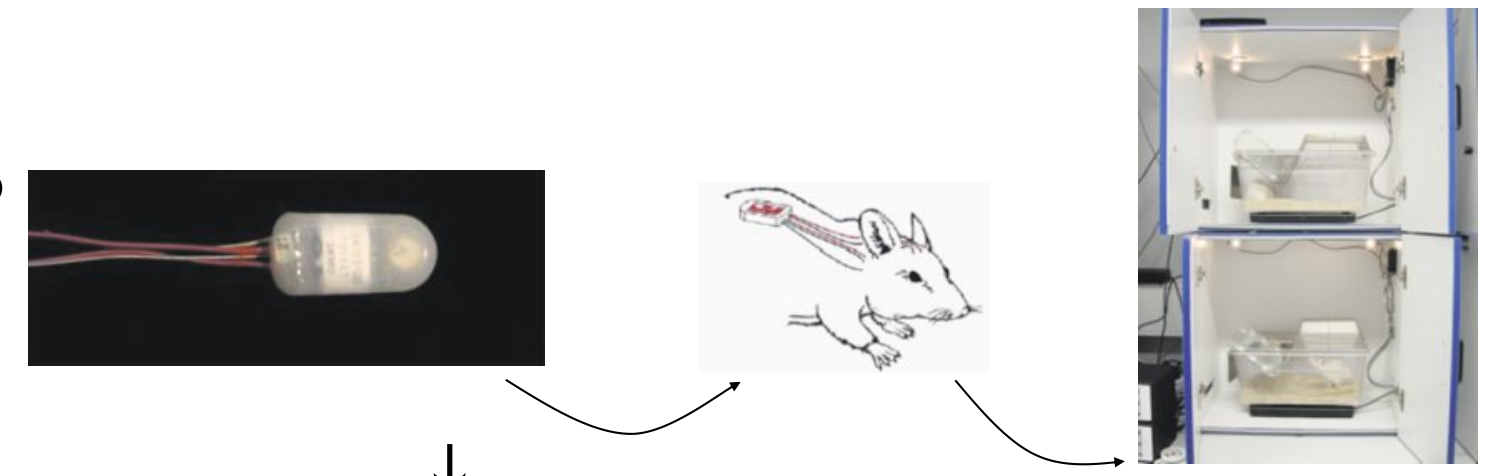

B)

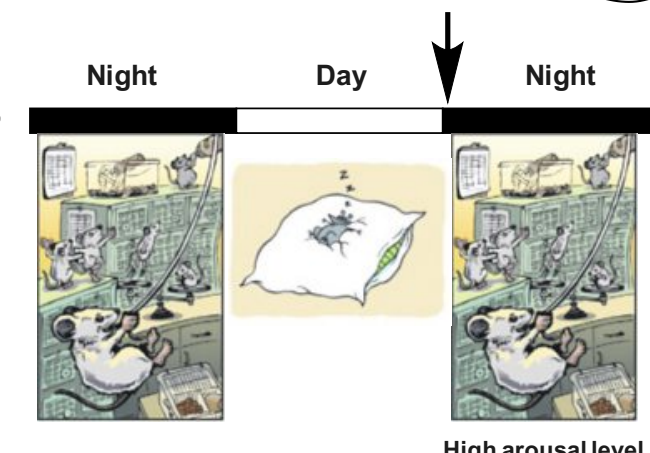

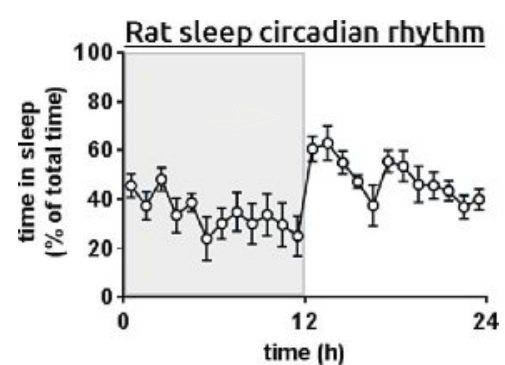

Sleep time is divided into: $\sim 75-85 \%$ non-REM sleep $\sim 15-25 \%$ REM sleep

Fig. 6. Orexin and sleep; Pharmacological setting. 
A)

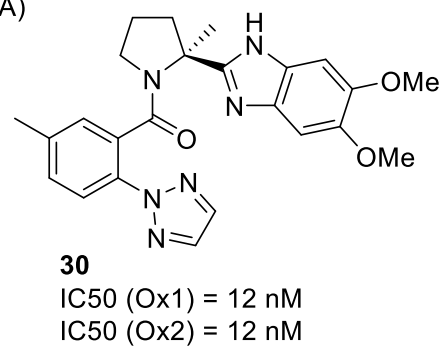

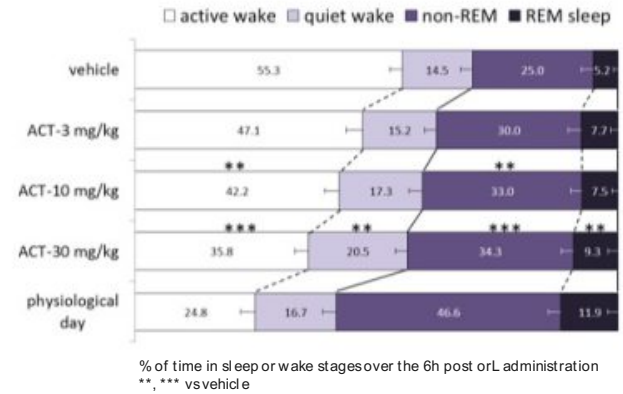

Fig. 7. Substitution of the benzimidazole compounds. (Detailed SAR investigation leading to daridorexant (37) will be published in due course.)
B)<smiles>Cc1ccc(-n2nccn2)c(C(=O)N2CCC[C@]2(C)c2nc3ccc(Cl)c(C)c3[nH]2)c1</smiles>

31

$\mathrm{Ki}(\mathrm{O} \times 1)=0.44 \mathrm{nM}$

$\mathrm{Ki}(\mathrm{O} \times 2)=0.93 \mathrm{nM}$<smiles>Cc1ccc(-n2nccn2)c(C(=O)N2CCC[C@]2(C)c2nc3cc(Cl)c(C(F)(F)F)cc3[nH]2)c1</smiles>

34

$\mathrm{IC} 50(\mathrm{O} \times 1)=1 \mathrm{nM}$

IC $50(O \times 2)=5 \mathrm{nM}$<smiles>Cc1ccc(-n2nccn2)c(C(=O)N2CCC[C@]2(C)c2nc3cc(Br)cc(C)c3[nH]2)c1</smiles>

32

$\mathrm{Ki}(\mathrm{Ox} 1)=5.2 \mathrm{nM}$

$\mathrm{Ki}(\mathrm{O} 2)=12.7 \mathrm{nM}$<smiles>Cc1ccc(-n2nccn2)c(C(=O)N2CCC[C@]2(C)c2nc3c(C)c(Cl)ccc3n2C)c1</smiles>

35

$\mathrm{Ki}(\mathrm{Ox} 1)=0.9 \mathrm{nM}$

$\mathrm{Ki}(\mathrm{O} \times 2)=1.0 \mathrm{nM}$ stability, plasma protein binding, brain penetration and physicochemical properties. We therefore broadly investigated the SAR on the benzoic acid part of the molecule attached to the pyrrolidine ring nitrogen atom (This will be published in due course elsewhere). This investigation, combined with sophisticated physiology based PK-PD modelling ${ }^{[3]}$ resulted in the selection of $\mathbf{3 7}$ (daridorexant) for preclinical and clinical development.

Fig. 8 summarizes the pharmacological assessment of $\mathbf{3 7}$ in rats at doses of $10 \mathrm{mg} / \mathrm{kg}, 30 \mathrm{mg} / \mathrm{kg}$ and $100 \mathrm{mg} / \mathrm{kg}$. The graph shows that $\mathbf{3 7}$ dose-dependently increased the time spent asleep while preserving NREM and REM sleep proportion and has the potential to improve sleep in insomniac patients. (Broad pharmacological characterization of $\mathbf{3 7}$ will be published elsewhere in due course) Compound $\mathbf{3 7}$ has recently delivered positive results

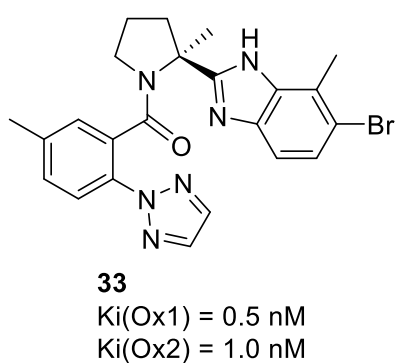<smiles>Cc1ccc(-n2nccn2)c(C(=O)N2CCC[C@]2(C)c2nc3ccc(Cl)c(C)c3[nH]2)n1</smiles>

36

$\mathrm{Ki}(\mathrm{Ox} 1)=4.1 \mathrm{nM}$

$\mathrm{Ki}(\mathrm{O} \times 2)=4 \mathrm{nM}$

in a first pivotal phase 3 clinical trial in insomniac patients indicating statistically significant positive effects on sleep and daytime performance. Further details will be released in due course. With that, the big challenge has been faced and the 'ideal' insomnia drug identified and proven to be useful to patients.

\section{The Long-term Companion: Combining Education, Drug Discovery and a Perfect Collaboration in the Quest for a Novel Antimalarial Drug}

\section{The Beginning}

At the inception of Actelion the founders decided to implement a second leg (in addition to the above discussed GPCRleg) consisting of aspartic protease targets. The most interest-<smiles>COc1ccc(-n2nccn2)c(C(=O)N2CCC[C@]2(C)c2nc3ccc(Cl)c(C)c3[nH]2)c1</smiles>

37 (Daridorexant) $\mathrm{Ki}(\mathrm{Ox} 1)=0.6 \mathrm{nM}$ $\mathrm{Ki}(\mathrm{Ox} 2)=0.9 \mathrm{nM}$
37 (daridorexant) $(\mathrm{mg} / \mathrm{kg}) \quad$ Active wake $₫$ Quiet wake $\|$ Non-REM sleep $\backsim$ REM sleep

Fig. 8. Pharmacological profile of daridorexant (37) in rats. 
ing aspartic protease targets at that time in industry were the HIV-protease and renin. We were very interested in renin as a cardiovascular target. In order to establish technology and generate experience with the target class, having a counter screen possibility available and to set up a crystallography lab, we also started to work on plasmepsin II (PMII), a malaria parasite specific aspartic protease. ${ }^{[44-46]}$ We mainly worked on this target with master students and in close collaboration with the Swiss TPH, who investigated our most potent PMII inhibitors in their red blood cell-based assays used to determine the antiparasitic activity of potentially new antimalaria drugs. ${ }^{[47]}$ We successfully crystallized some of our most potent inhibitors in the enzyme. ${ }^{[48]}$ However our enzyme inhibitory activity never really translated into antiparasitic activity in the red blood cell (RBC) assay. We and others found that inhibiting only PMII, in the presence of several other plasmepsins in the malaria parasite, did not really harm the parasite. It became clear that one would have to inhibit several plasmepsins in parallel to kill the parasite. We therefore abandoned this approach but decided to continue our research in the field of antimalarials. We started the project in a completely different manner again in very close collaboration with the Swiss TPH.

\section{The Second Try}

First a few words about malaria. Malaria persists as a significant health problem in large areas of the world. The World Malaria Report 2017 from the World Health Organization, identified 216 million malaria cases in 2016, leading to 445000 deaths, compared with 237 million cases in 2010 and 211 million cases in 2015. (World Health Organization WHO, World Malaria Report, 2017; http://www.who.int/malaria/publications/world-malariareport-2017/en) Even dedicated efforts over several decades did not allow to control and eradicate malaria. It remains a leading cause of death worldwide, with dramatic impacts on public health and economic development in the poorest regions of the planet. The highest number of cases appear in sub-Saharan Africa, followed by South-East Asia. The alarming recent increase of $\sim 5$ million cases is due to the emergence of parasites resistant to the gold standard artemisinin combination therapy (ACT), to the absence of malaria vaccines and the limited chemotherapeutic alternatives to ACTs. The severity of the problem is also associated with increased mobility of populations, climate change, novel agricultural habits, political conflicts and mosquito vectors resistant to pesticides. A recent overview describes the latest progress in the quest for novel small molecule antimalarials. ${ }^{[49]}$ Malaria is caused by a protozoan parasite of the genus Plasmodium. Five different species are relevant for humans: $P$. falciparum, $P$. vivax, P. ovale, P.malariae, $P$. knowlesi. Malaria is the most widespread parasitic disease in man, with approximately 2 billion people at risk of infection. P. falciparum causes most of the malaria associated deaths.

The requirements which antimalarial drugs need to fulfill are demanding and listed here: A novel antimalarial drug must be active against chloroquine- (CQ) sensitive as well as CQ-resistant strains. It has to offer a fast onset of action, needs to be structurally different from marketed antimalarials and chemically stable. It should work via a novel mechanism of action. Its production needs to be cheap. The drug has to be orally active, should cure the patient in 1 to 3 days, must exhibit a low potential to induce parasite resistance and must be suitable for combinations with other antimalarial drugs. The safety profile must allow for use in children and pregnant women.

We started out the second try of our endeavor by screening 5000 randomly selected compounds from our screening compound collection in an erythrocyte-based phenotypic screen against the CQ-resistant K1 strain of P. falciparum. Phenylalanine-based compound $\mathbf{3 8}$ was identified as an attractive hit as it offered a plethora of modification possibilities and appealing initial antimalarial activity of $3.8 \mathrm{nM} .{ }^{[4]}$ Many rounds of SAR work (many students, several master thesis' and a lot of molecules synthesized) and screening in different albumax and serum containing assay media, followed by broad in vivo pharmacokinetic and pharmacodynamic investigation resulted in the selection of $\mathbf{3 9}$ as candidate for preclinical development (Fig. 9). [50]
Fig. 9. From screening hit $\mathbf{3 8}$ to drug candidate 39 (ACT-451840).

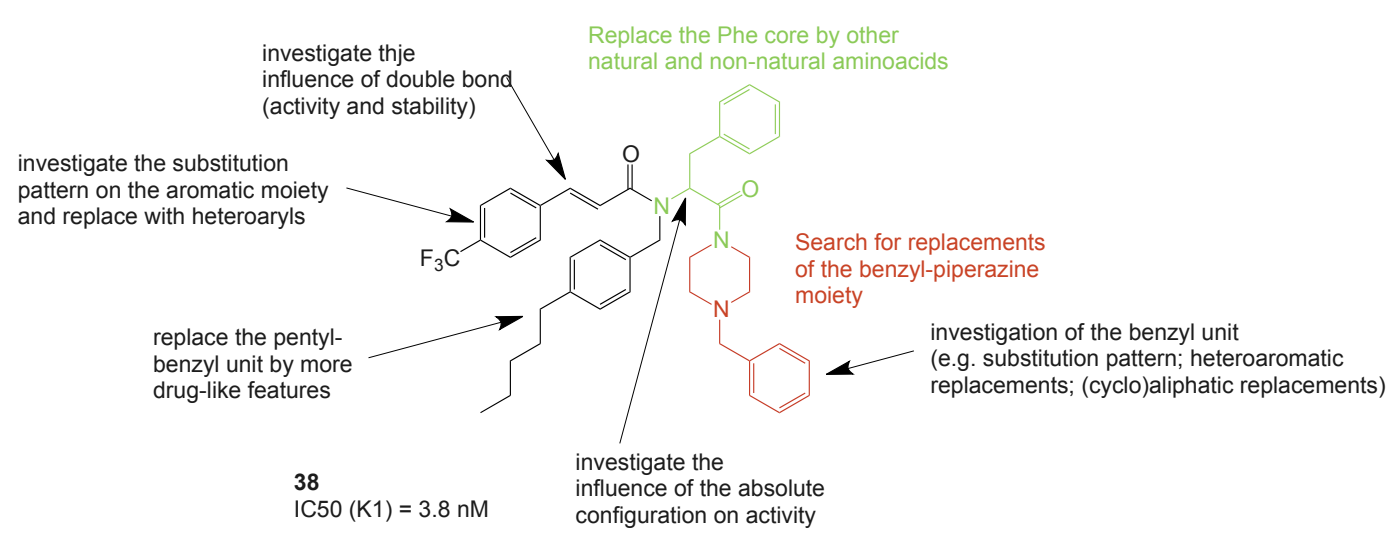

Many Students

Several Master Thesis

A lot of molecules

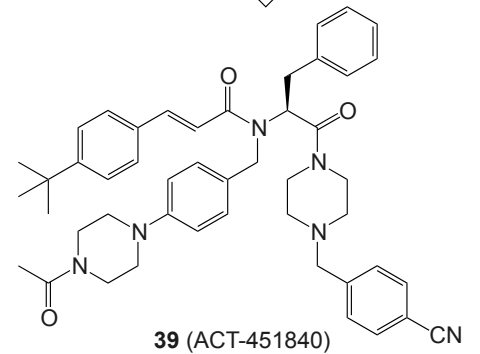


Compound 39 showed very good activity against a panel of several CQ-resistant and -sensitive $P$. falciparum strains. It exhibited a low frequency of resistance development, showed a fast onset of action in vitro and in vivo in two different mouse models (P. berghei; $P$. falciparum in immunocompromised mice; in a $P$. berghei infected mouse experiment, cure by 39 was achieved after administration of $300 \mathrm{mg} / \mathrm{kg}$ po on 3 consecutive days), and excellent activity against all stages of the parasite life cycle (rings, trophozoites and schizonts), resulting in blocking of transmission. The compound did not show safety flags (no genotoxicity, no CNS side effects, no effects on cardiovascular parameters, no signs of gastrointestinal toxicity). Compound 39 was clinically investigated to address safety, tolerability and pharmacokinetics at single doses of $10,50,200$ and $500 \mathrm{mg}$ in healthy male subjects. ${ }^{[51]}$ Compound 39 was well tolerated in all investigated doses. In the $200 \mathrm{mg}$ and $500 \mathrm{mg}$ groups, the effect of food on the PK parameters was also well investigated. The AUC under fed conditions $(1408 \mathrm{ng} * \mathrm{~h} / \mathrm{ml})$ was about 13 times higher than under fasted conditions but food did not affect half-life which was in the range of 34 hours. Tmax under fasted conditions was $2 \mathrm{~h}$ and under fed conditions was $3.5 \mathrm{~h}$. The compound has been tested at $500 \mathrm{mg}$ under fed conditions, in an experimental human malaria infection model in a clinical trial developed by Medicines for Malaria Venture (MMV) and QIMR Berghofer Medical Research Institute in Brisbane, AU. ${ }^{[52]}$ This experiment confirmed the fast onset of action of $\mathbf{3 9}$ and the gametocytocidal effect. Further studies should clarify the potential of $\mathbf{3 9}$ to function as an artemisinin surrogate in ACTs. An important aspect of the attractiveness of the compound is its mechanism of action, ${ }^{[53]}$ which is distinct from the mechanism of action of the 'peroxide' antimalarials.

\section{Regular Frustration in a Medicinal Chemist's Life - Hit Structures from High-throughput Screens. What to do against it? Improve the Screening Compound Collection!}

In pharma industry, also at Idorsia Pharmaceuticals Ltd, we rely strongly on high-throughput screening campaigns to initiate drug discovery projects on validated targets. Experience collected in the early career days often resulted in astonished frustration about the chemical quality of the hits, resulting from HTS campaigns. In 2012, at that time with Actelion Pharmaceuticals, we decided to tackle the aspect of chemical quality and attractiveness of our screening compound collection. ${ }^{5]}$ The important organizational step in this process was the implementation of the Compound Library Committee (CLC), consisting of computational scientists, medicinal chemists and a biologist. The CLC's task was to acquire new compounds for our screening compound collection. Based on an analysis of the screening compound collection as of 2012, the CLC developed a 'New Library Strategy'. Key elements of the 'New Library Strategy' were:

- continuous library turnover mode (see Fig. 10)

- library size of 300'000 compounds

- select 'lead-like' instead of 'drug-like' structures (see Fig. 11) - enrich for non-flat structures and aim for compound novelty by increasing the ratio for high prize 'Premium Compounds'

- add novel chemical space by natural products, macrocycles, compound exchanges with agrochemical companies

Already several years ago, Actelion decided to implement a 'Library Rolling Mode' and restrict the size of the active screening compound collection to 300'000 compounds. The 'Rolling Mode' is graphically depicted in Fig. 10. As can be seen the active screening compound collection of 300'000 compounds consists of 5 subsets of 60'000 compounds. This means that a specific compound will be part of the active screening compound collection for 5 years and after that, will be removed and replaced by newly acquired compounds. This functioning has the advantage of increased sample quality by avoiding aging beyond 5 years. Every year we change the library composition by removing 60 ' 000 compounds on one end and adding 60'000 compounds on the other end. Restricting the screening compound collection to 300'000 compounds has a big impact on the compound selection. The Actelion Idorsia screening library contains a significant number of singletons in order to cover the pharmaceutically interesting chemical space with a rather low number of compounds. In addition, vendors very often have compounds available for about 5 years, which supports the 'Rolling Mode' approach. It allows by targeted purchase of diversity-wise close neighbors, fast hit expansions on identified singletons.

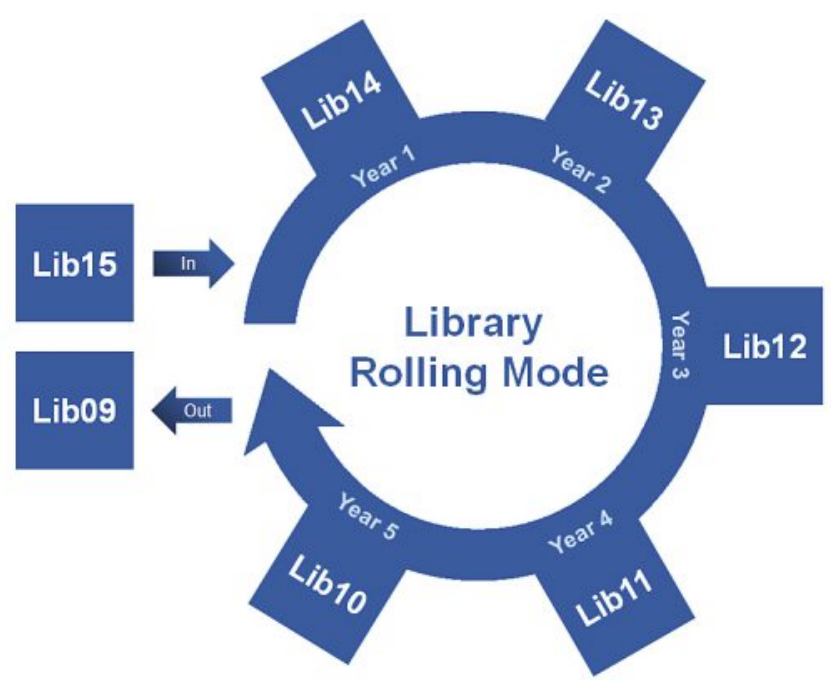

Fig. 10. The 'rolling mode' of the Actelion/ldorsia screening compound collection.

In order to achieve the lead-like and non-flat compounds enrichment in the Actelion/Idorsia screening compound collection, the CLC defined the eight scoring functions, reflecting physical and physico-chemical properties, depicted in Fig. 11 (MW, clogP, HBA, HBD, Molecular Flexibility, aromatic ring count, Fsp3 and stereocenter count) and used them to define our own multiparameter optimization (MPO) scoring algorithm. This was adapted from a published approach on CNS MPO scores calculations. ${ }^{[54,55]}$ The parameters were selected based on the following thoughts. The size of compounds usually increases in medicinal chemistry programs. Therefore, compounds with $\mathrm{MW}<400$ were preferred. High lipophilicity is often associated with an elevated risk of promiscuously interacting with proteins, resulting in selectivity issues and off-target toxicity. High lipophilicity is as well often associated with limited metabolic stability. On the other hand, very hydrophilic molecules are usually less membrane permeable. That is why we set the optimal clogP from -2 to 2 . Drug development success can be associated to the number of aromatic rings in a molecule. It should remain below 4.[56] To increase three dimensionality and 'Escape from Flatland', ${ }^{[57]}$ Fsp3 and the presence of chiral centers were considered important. The number of Hydrogen Bond Acceptors (HBA) and Hydrogen Bond Donors (HBD) are important for permeability and were therefore as well taken into account. Molecular flexibility is a predictor for oral bioavailability and was set to 0.20 to $0.55 .{ }^{[58]}$ Using the MPO concept for the compound selection allows for enhanced flexibility beyond the use of single parameters or hard cutoffs and should allow to identify compounds with greater probability of success.

Compounds passing these criteria were afterwards further analyzed by substructure filtering. Compounds containing unwanted chemical functionalities and features were eliminated. The remaining compounds were compared to the remaining part of the screening compound collection to ensure optimal coverage 

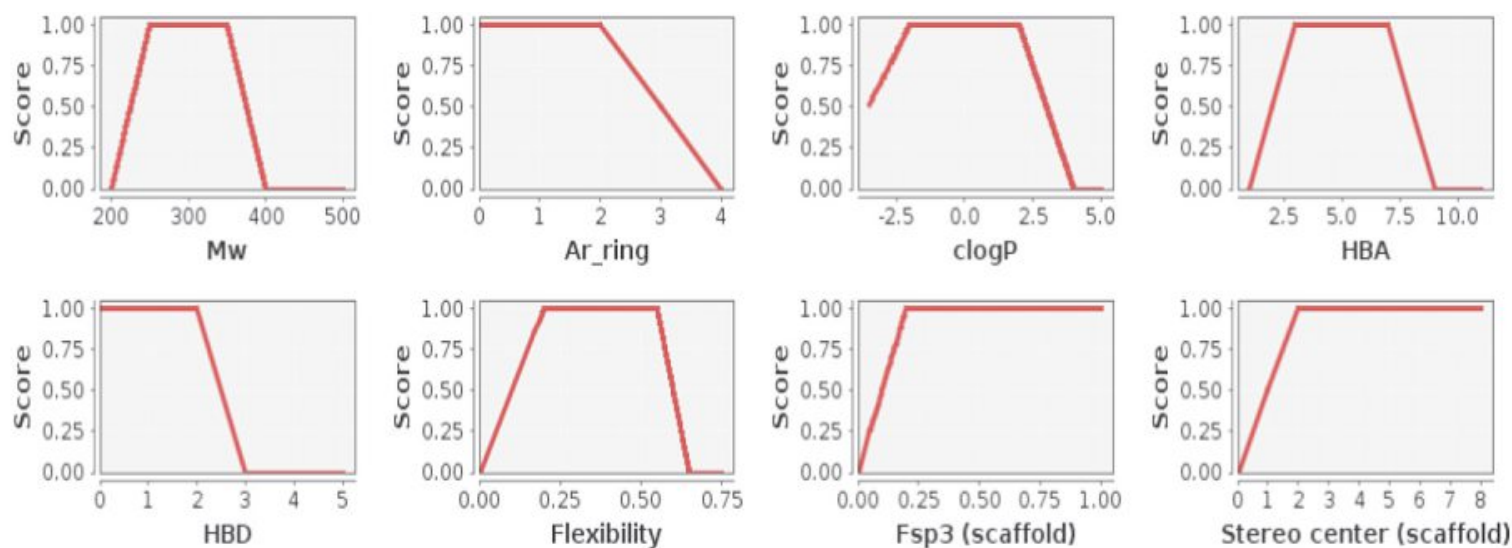

Fig. 11. Each plot represents a physicochemical property desirability function used to generate our lead-like MPO. Multiparameter optimization methods are commonly used to assess and balance the effects of several variables, weighted based on their importance to the overall objective.

of the chemical space by gap-filling. And finally clustering and a dissimilarity selection step were performed to obtain an optimal selection to be entered into the screening compound collection every year.

A comparative analysis of Library 12 (compounds acquired in 2012 and added to the screening compound collection as Lib12) and Library 15 (compounds acquired in 2015 and added to the screening compound collection as Lib15) on two parameters is exemplified in Fig. 12. It clearly shows the impact the measures taken by the CLC had on the change of properties of the purchased compounds. In Fig. 12A the shift towards compounds with lower molecular weight becomes visible and is a direct consequence of the above-described definition of the molecular weight parameter range. Fig. 12B graphically shows the impact of the strategic decision to enhance the exclusivity of the screening compound collection. In Library 12 we had only $14 \%$ exclusive compounds whereas in Library 15 this was increased to $47 \%$. A more detailed analysis can be found in ref. [5].

The measures taken by the CLC resulted in an improved screening compound collection which has so far delivered several very promising hits, including macrocycles, that are followed up in Hit-to-Lead and Lead Optimization programs at Idorsia Pharmaceuticals Ltd. It is important to mention, that the goal of the CLC was not to obtain increased hit rates but to identify chemically attractive compounds as screening hits, offering possibilities to Hit-to-Lead as well as medicinal chemists for further modification into leads and future drugs.

\section{Conclusions}

The four stories give an overview of more than 20 years of medicinal chemistry and pharma research the author was involved in and allow for several key learnings. In order to progress in a drug discovery project, it is very helpful to have access to reliable and relevant animal models and biological and biochemical assays. Considering the large numbers of molecules synthesized from the screening hit to the starting point and from there to the compound selected for clinical development, drug molecules have to be considered as exceptions. Drug discovery is not following rules, the maximum help medicinal chemists can expect are guidelines. Drug discovery is not a linear process and is accompanied by regular setbacks. It asks for patience and demands a lot of persistence. In order to be successful, a bit of luck may be helpful. In case of success it is important to remain humble and modest because success is a small part of the full effort and each and every contribution on the way is needed, even those, or maybe especially those, leading into dead-ends and detours. Every project is different and special. If you structure your work, paper writing at the end will be easier ;-).

The best advice I got during my career was: “Don't try to be too smart, you may fool yourself". And the absolute most important learning: Drug discovery is highly complex. Teamwork is key. All the different experts from the different disciplines need to make their contribution. Only together can one do it.

\section{Acknowledgements:}

I met a very large number of colleagues over the years. I had the privilege to be involved in several extremely interesting and ultimately successful projects. It was a tremendously stimulating experience. I cannot name all colleagues who contributed to these successes but just mention a few representatives: Walter Fischli, for having hired me at Actelion even though I had a suboptimal CV. Thomas Weller, who was my line manager and mentor for almost 20 years. Jean-Paul Clozel for his trust and the tremendous opportunity he offered to me. Karl-Heinz Altmann for the best ever piece of advice. Pascal Rebmann, for his patience, flexibility and efficiency during 15 years of direct and intense collaboration.
A)

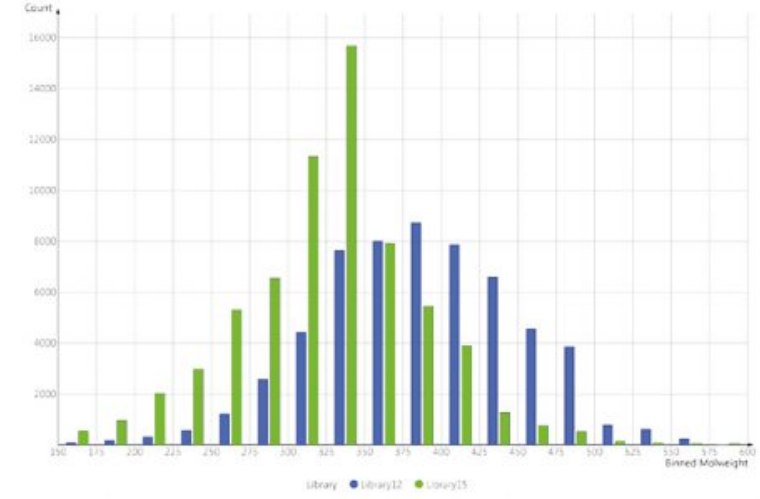

B)
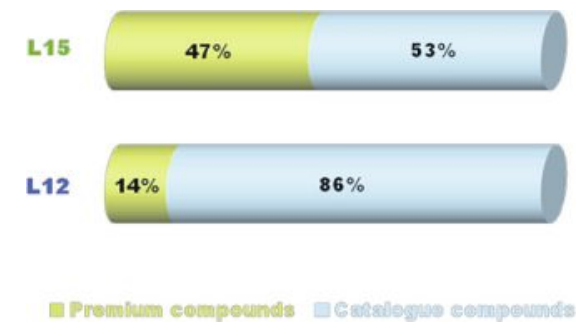

Fig. 12. A) Molecular weight distribution of L12 (in blue) compared to L15 (in green); B) Premium compounds versus catalogue compounds of L12 (bottom) compared to L15 (top). 
Sergio Wittlin for a perfect collaborative experience over many years. Thierry Langer for offering opportunities to me to interact with young students and for his friendship. Catherine Roch for her huge contribution, not only to the orexin receptor antagonist project. The Swiss Chemical Society for the SICS 2019 prize.

Received: May 29, 2020

[1] M. H. Bolli, C. Boss, C. Binkert, S. Buchmann, D. Bur, P. Hess, M. Iglarz, S. Meyer, J. Rein, M. Rey, A. Treiber, M. Clozel, W. Fischli, T. Weller, J. Med. Chem. 2012, 55, 7849 .

[2] C. Boss, C. Roch-Brisbare, M. A. Steiner, A. Treiber, H. Dietrich, F. Jenck, M. von Raumer, T. Sifferlen, C. Brotschi, B. Heidmann, J. T. Williams, H. Aissaoui, R. Siegrist, J. Gatfield, ChemMedChem 2014, 9, 2486.

[3] A. Treiber, R. de Kanter, C. Roch, J. Gatfield, C. Boss, M. von Raumer, B. Schindelholz, C. Muehlan, J. van Gerven, F. Jenck, J. Pharmacol. Exp. Ther. 2017, 362, 489 .

[4] C. Boss, H. Aissaoui, N. Amaral, A. Bauer, S. Bazire, C. Binkert, R. Brun, C. Burki, C. L. Ciana, O. Corminboeuf, S. Delahaye, C. Dollinger, C. Fischli, W. Fischli, A. Flock, M. C. Frantz, M. Girault, C. Grisostomi, A. Friedli, B. Heidmann, C. Hinder, G. Jacob, A. Le Bihan, S. Malrieu, S. Mamzed, A. Merot, S. Meyer, S. Peixoto, N. Petit, R. Siegrist, J. Trollux, T. Weller, S. Wittlin, ChemMedChem 2016, 11, 1995.

[5] C. Boss, J. Hazemann, T. Kimmerlin, M. von Korff, U. Luthi, O. Peter, T. Sander, R. Siegrist, Chimia 2017, 71, 667.

[6] M. Clozel, W. Fischli, J. Cardiovasc. Pharmacol. 1989, 13 Suppl 5, S229.

[7] W. Fischli, M. Clozel, C. Guilly, Life Sci. 1989, 44, 1429.

[8] M. Clozel, W. Fischli, C. Guilly, J. Clin. Invest. 1989, 83, 1758.

[9] M. Clozel, V. Breu, K. Burri, J. M. Cassal, W. Fischli, G. A. Gray, G. Hirth, B. M. Loffler, M. Muller, W. Neidhart, H. Ramuz, Nature 1993, 365, 759.

[10] P. H. Dagassan, V. Breu, M. Clozel, A. Kunzli, P. Vogt, M. Turina, W. Kiowski, J. P. Clozel, J. Cardiovasc. Pharmacol. 1996, 27, 147.

[11] C. Weber, R. Schmitt, H. Birnboeck, G. Hopfgartner, S. P. van Marle, P. A. Peeters, J. H. Jonkman, C. R. Jones, Clin. Pharmacol. Ther. 1996, 60, 124.

[12] M. Clozel, V. Breu, G. A. Gray, B. Kalina, B. M. Loffler, K. Burri, J. M. Cassal, G. Hirth, M. Muller, W. Neidhart, J. Pharmacol. Exp. Ther. 1994, $270,228$.

[13] M. H. Bolli, Chimia 2017, 71, 420

[14] T. F. Luscher, V. Richard, M. Tschudi, Z. H. Yang, C. Boulanger, J. Am. Coll. Cardiol. 1990, 15, 519.

[15] C. Boulanger, T. F. Luscher, J. Clin. Invest. 1990, 85, 587.

[16] T. Sakurai, M. Yanagisawa, T. Masaki, Trends Pharmacol. Sci. 1992, 13, 103.

[17] C. Boss, M. H. Bolli, J. Gatfield, Bioorg. Med. Chem. Lett. 2016, 26, 3381.

[18] P. Mulder, V. Richard, G. Derumeaux, M. Hogie, J. P. Henry, F. Lallemand, P. Compagnon, B. Mace, E. Comoy, B. Letac, C. Thuillez, Circulation 1997, 96, 1976.

[19] B. Hocher, P. Kalk, T. Slowinski, M. Godes, A. Mach, S. Herzfeld, D. Wiesner, P. C. Arck, H. H. Neumayer, B. Nafz, J. Am. Soc. Nephrol. 2003, $14,367$.

[20] C. Boss, M. Bolli, T. Weller, Curr. Med. Chem. 2002, 9, 349.

[21] M. H. Bolli, C. Boss, J. Gatfield, M. Iglarz, A. Treiber, in 'Comprehensive Medicinal Chemistry III', 2017, pp. 252.

[22] A. E. Nassar, A. M. Kamel, C. Clarimont, Drug Discov. Today 2004, 9, 1020

[23] A. E. Nassar, A. M. Kamel, C. Clarimont, Drug Discov. Today 2004, 9, 1055.

[24] A. L. Hopkins, G. M. Keseru, P. D. Leeson, D. C. Rees, C. H. Reynolds, Nat. Rev. Drug Discov. 2014, 13, 105.

[25] a) L. de Lecea, T. S. Kilduff, C. Peyron, X. Gao, P. E. Foye, P. E. Danielson, C. Fukuhara, E. L. Battenberg, V. T. Gautvik, F. S. Bartlett, 2nd, W. N. Frankel, A. N. van den Pol, F. E. Bloom, K. M. Gautvik, J. G. Sutcliffe, Proc. Natl Acad. Sci. USA 1998, 95, 322; b) T. Sakurai, A. Amemiya, M. Ishii, I. Matsuzaki, R. M. Chemelli, H. Tanaka, S. C. Williams, J. A. Richarson, G. P. Kozlowski, S. Wilson, J. R. Arch, R. E. Buckingham, A. C. Haynes, S. A. Carr, R. S. Annan, D. E. McNulty, W. S. Liu, J. A. Terrett, N. A. Elshourbagy, D. J. Bergsma, M. Yanagisawa, Cell 1998, 92, 1 page following 696.

[26] a) L. de Lecea, Prog. Brain. Res. 2012, 198, 15; b) T. Sakurai, Nat. Rev. Neurosci. 2007, 8, 171; c) T. E. Scammell, E. Arrigoni, J. O. Lipton, Neuron 2017, 93, 747 .

[27] H. S. Randeva, E. Karteris, D. Grammatopoulos, E. W. Hillhouse, J. Clin. Endocrinol. Metab. 2001, 86, 4808.

[28] K. N. Nilaweera, P. Barrett, J. G. Mercer, P. J. Morgan, Neuroscience 2003, 119,713 .

[29] C. Peyron, D. K. Tighe, A. N. van den Pol, L. de Lecea, H. C. Heller, J. G. Sutcliffe, T. S. Kilduff, J. Neurosci. 1998, 18, 9996.

[30] a) E. Eggermann, M. Serafin, L. Bayer, D. Machard, B. Saint-Mleux, B. E. Jones, M. Muhlethaler, Neuroscience 2001, 108, 177; b) J. J. Hagan, R. A. Leslie, S. Patel, M. L. Evans, T. A. Wattam, S. Holmes, C. D. Benham, S. G. Taylor, C. Routledge, P. Hemmati, R. P. Munton, T. E. Ashmeade, A. S. Shah, J. P. Hatcher, P. D. Hatcher, D. N. Jones, M. I. Smith, D. C. Piper, A. J. Hunter, R. A. Porter, N. Upton, Proc. Natl Acad. Sci. USA 1999, 96,
10911; c) M. G. Lee, O. K. Hassani, B. E. Jones, J. Neurosci. 2005, 25, 6716; d) R. J. Liu, A. N. van den Pol, G. K. Aghajanian, J. Neurosci. 2002, 22, 9453; e) A. Yamanaka, N. Tsujino, H. Funahashi, K. Honda, J. L. Guan, Q. P. Wang, M. Tominaga, K. Goto, S. Shioda, T. Sakurai, Biochem. Biophys. Res. Commun. 2002, 290, 1237.

[31] M. Mieda, E. Hasegawa, Y. Y. Kisanuki, C. M. Sinton, M. Yanagisawa, T. Sakurai, J. Neurosci. 2011, 31, 6518.

[32] a) L. Lin, J. Faraco, R. Li, H. Kadotani, W. Rogers, X. Lin, X. Qiu, P. J. de Jong, S. Nishino, E. Mignot, Cell 1999, 98, 365; b) R. M. Chemelli, J. T. Willie, C. M. Sinton, J. K. Elmquist, T. Scammell, C. Lee, J. A. Richardson, S. C. Williams, Y. Xiong, Y. Kisanuki, T. E. Fitch, M. Nakazato, R. E. Hammer, C. B. Saper, M. Yanagisawa, Cell 1999, 98, 437; c) C. Peyron, J. Faraco, W. Rogers, B. Ripley, S. Overeem, Y. Charnay, S. Nevsimalova, M. Aldrich, D. Reynolds, R. Albin, R. Li, M. Hungs, M. Pedrazzoli, M. Padigaru, M. Kucherlapati, J. Fan, R. Maki, G. J. Lammers, C. Bouras, R. Kucherlapati, S. Nishino, E. Mignot, Nat. Med. 2000, 6, 991; d) T. C. Thannickal, R. Y. Moore, R. Nienhuis, L. Ramanathan, S. Gulyani, M Aldrich, M. Cornford, J. M. Siegel, Neuron 2000, 27, 469; e) J. T. Willie, R. M. Chemelli, C. M. Sinton, S. Tokita, S. C. Williams, Y. Y. Kisanuki, J. N. Marcus, C. Lee, J. K. Elmquist, K. A. Kohlmeier, C. S. Leonard, J. A. Richardson, R. E. Hammer, M. Yanagisawa, Neuron 2003, 38, 715; f) Y Yoshida, N. Fujiki, T. Nakajima, B. Ripley, H. Matsumura, H. Yoneda, E. Mignot, S. Nishino, Eur. J. Neurosci. 2001, 14, 1075; g) R. M. Salomon, B. Ripley, J. S. Kennedy, B. Johnson, D. Schmidt, J. M. Zeitzer, S. Nishino, E. Mignot, Biol. Psychiatry 2003, 54, 96; h) A. L. Gotter, A. L. Webber, P. J. Coleman, J. J. Renger, C. J. Winrow, Pharmacol. Rev. 2012, 64, 389.

[33] C. Brisbare-Roch, J. Dingemanse, R. Koberstein, P. Hoever, H. Aissaoui, S. Flores, C. Mueller, O. Nayler, J. van Gerven, S. L. de Haas, P. Hess, C. Qiu, S. Buchmann, M. Scherz, T. Weller, W. Fischli, M. Clozel, F. Jenck, Nat. Med. 2007, 13, 150

[34] a) S. V. Fox, A. L. Gotter, S. J. Tye, S. L. Garson, A. T. Savitz, J. M. Uslaner, J. I. Brunner, P. L. Tannenbaum, T. P. McDonald, R. Hodgson, L. Yao, M. R. Bowlby, S. D. Kuduk, P. J. Coleman, R. Hargreaves, C. J. Winrow, J. J. Renger, Neuropsychopharmacology 2013, 38, 2401; b) A. L. Gotter, S. L. Garson, J. Stevens, R. L. Munden, S. V. Fox, P. L. Tannenbaum, L. Yao, S. D. Kuduk, T. McDonald, J. M. Uslaner, S. J. Tye, P. J. Coleman, C. J. Winrow, J. J. Renger, BMC Neurosci. 2014, 15, 109; c) P. L. Tannenbaum, J. Stevens, J. Binns, A. T. Savitz, S. L. Garson, S. V. Fox, P. Coleman, S. D. Kuduk, A. L. Gotter, M. Marino, S. J. Tye, J. M. Uslaner, C. J. Winrow, J. J. Renger, Front. Behav. Neurosci. 2014, 8, 182.

[35] C. Boss, C. Brisbare-Roch, F. Jenck, H. Aissaoui, R. Koberstein, T. Sifferlen, T. Weller, Chimia 2008, 62, 974.

[36] P. Hoever, G. Dorffner, H. Benes, T. Penzel, H. Danker-Hopfe, M. J. Barbanoj, G. Pillar, B. Saletu, O. Polo, D. Kunz, J. Zeitlhofer, S. Berg, M. Partinen, C. L. Bassetti, B. Hogl, I. O. Ebrahim, E. Holsboer-Trachsler, H. Bengtsson, Y. Peker, U. M. Hemmeter, E. Chiossi, G. Hajak, J. Dingemanse, Clin. Pharmacol. Ther. 2012, 91, 975.

[37] A. J. Roecker, C. D. Cox, P. J. Coleman, J. Med. Chem. 2016, 59, 504.

[38] H. G. Cruz, P. Hoever, B. Chakraborty, K. Schoedel, E. M. Sellers, J. Dingemanse, CNS Drugs 2014, 28, 361.

[39] M. Hoch, H. van Gorsel, J. van Gerven, J. Dingemanse, J. Clin. Pharmacol. 2014, 54, 979 .

[40] M. Carskadon, W. Dement, in 'Principles and Practice of Sleep Medicine', 5th ed., Eds.: M. H. Kryger, T. Roth, W. Dement, Elsevier, 2011, pp. 16.

[41] M. G. Frank, Rev. Neurosci. 2006, 17, 375.

[42] J. C. Levenson, D. B. Kay, D. J. Buysse, Chest 2015, 147, 1179.

[43] a) M. Modirrousta, L. Mainville, B. E. Jones, Eur. J. Neurosci. 2005, 21, 2807; b) J. M. Zeitzer, C. L. Buckmaster, K. J. Parker, C. M. Hauck, D. M. Lyons, E. Mignot, J. Neurosci. 2003, 23, 3555.

[44] C. Boss, S. Richard-Bildstein, T. Weller, W. Fischli, S. Meyer, C. Binkert, Curr. Med. Chem. 2003, 10, 883.

[45] C. Boss, S. Richard Bildstein, R. Furnari, J.-M. Bourgeois, O. Corminboeuf, C. Grisostomi, L. Coppex, L. Harris, L. Prade, S. Meyer, C. Binkert, W. Fischli, R. Brun, T. Weller, Chimia 2004, 58, 634.

[46] C. Boss, O. Corminboeuf, C. Grisostomi, T. Weller, Exp. Opin. Therapeutic Patents 2006, 16, 295

[47] O. Corminboeuf, G. Dunet, M. Hafsi, J. Grimont, C. Grisostomi, S. Meyer, C. Binkert, D. Bur, A. Jones, L. Prade, R. Brun, C. Boss, Bioorg. Med. Chem. Lett. 2006, 16, 6194.

[48] C. Boss, O. Corminboeuf, C. Grisostomi, S. Meyer, A. F. Jones, L. Prade, C. Binkert, W. Fischli, T. Weller, D. Bur, ChemMedChem 2006, 1, 1341.

[49] C. Boss, S. Wittlin, Med. Chem. Rev. 2018, 53, 293.

[50] A. Le Bihan, R. de Kanter, I. Angulo-Barturen, C. Binkert, C. Boss, R. Brun, R. Brunner, S. Buchmann, J. Burrows, K. J. Dechering, M. Delves, S. Ewerling, S. Ferrer, C. Fischli, F. J. Gamo-Benito, N. F. Gnadig, B. Heidmann, M. B. Jimenez-Diaz, D. Leroy, M. S. Martinez, S. Meyer, J. J Moehrle, C. L. Ng, R. Noviyanti, A. Ruecker, L. M. Sanz, R. W. Sauerwein, C. Scheurer, S. Schleiferboeck, R. Sinden, C. Snyder, J. Straimer, G. Wirjanata, J. Marfurt, R. N. Price, T. Weller, W. Fischli, D. A. Fidock, M. Clozel, S. Wittlin, PLoS Med. 2016, 13, e1002138.

[51] S. Bruderer, N. Hurst, R. de Kanter, T. Miraval, T. Pfeifer, Y. Donazzolo, J. Dingemanse, Antimicrob. Agents Chemother. 2015, 59, 935. 
[52] A. Krause, J. Dingemanse, A. Mathis, L. Marquart, J. J. Mohrle, J. S. McCarthy, Br. J. Clin. Pharmacol. 2016, 82, 412

[53] a) R. Brunner, H. Aissaoui, C. Boss, Z. Bozdech, R. Brun, O. Corminboeuf, S. Delahaye, C. Fischli, B. Heidmann, M. Kaiser, J. Kamber, S. Meyer, P. Papastogiannidis, R. Siegrist, T. Voss, R. Welford, S. Wittlin, C. Binkert, J. Infect. Dis. 2012, 206, 735; b) R. Brunner, C. L. Ng, H. Aissaoui, M. H. Akabas, C. Boss, R. Brun, P. S. Callaghan, O. Corminboeuf, D. A. Fidock, I. J. Frame, B. Heidmann, A. Le Bihan, P. Jeno, C. Mattheis, S. Moes, I. B. Muller, M. Paguio, P. D. Roepe, R. Siegrist, T. Voss, R. W. Welford, S. Wittlin, C. Binkert, J. Biol. Chem. 2013, 288, 22576.

[54] T. T. Wager, R. Y. Chandrasekaran, X. Hou, M. D. Troutman, P. R. Verhoest, A. Villalobos, Y. Will, ACS Chem. Neurosci. 2010, 1, 420

[55] T. T. Wager, X. Hou, P. R. Verhoest, A. Villalobos, ACS Chem. Neurosci. 2010, 1,435 .

[56] T. J. Ritchie, S. J. Macdonald, Drug Discov. Today 2009, 14, 1011.
[57] F. Lovering, J. Bikker, C. Humblet, J. Med. Chem. 2009, 52, 6752.

[58] D. F. Veber, S. R. Johnson, H. Y. Cheng, B. R. Smith, K. W. Ward, K. D. Kopple, J. Med. Chem. 2002, 45, 2615.

\section{License and Terms}

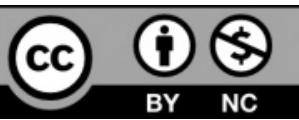

This is an Open Access article under the terms of the Creative Commons Attribution License CC BY_NC 4.0. The material may not be used for commercial purposes.

The license is subject to the CHIMIA terms and conditions: (http:// chimia.ch/component/sppagebuilder/?view=page \&id=12).

The definitive version of this article is the electronic one that can be found at doi:10.2533/chimia.2020.549 